\title{
TOWARDS ENDURANCE IN SPORT
}

Dragan Radovanovic

Faculty of Sport and Physical Education University of Nis, Serbia

\section{IZDRŽLJIVOST U SPORTU

\author{
Dragan Radovanović
}

Fakultet sporta i fizičkog vaspitanja Univerziteta u Nišu

\section{ABSTRACT}

Cardiorespiratory endurance, which is also known as aerobic endurance, is the ability of the whole body to sustain prolonged exercise involving relatively large muscle groups. Muscle endurance is defined as the ability of a muscle group to execute repeated contractions over a period of time that is sufficient to cause muscular fatigue or as the ability to maintain a specific percentage of the maximum voluntary contraction for a prolonged period of time. Each version of muscle endurance plays a unique role in sport activities, and each has a special importance to various athletes. Cardiorespiratory endurance is thought to be the most important component of physical fitness. Low endurance capacity leads to exhaustion, even in sports and activities characterised by low dynamics. The combination of spiroergometric testing (with appropriate testing protocols) and the measurements of lactate thresholds is believed to be the gold standard in the assessment of cardiorespiratory endurance. The generated parameters are then used to define the training objectives, to preparefor a precise training plan and program, and to evaluate the effects of the subsequent training effect evaluation. Muscular endurance is specific for each group of muscle, type, and velocity of contraction. Due to the specificity of muscular endurance, a universal assessment of the muscular endurance of the whole body has not yet been developed. Isokinetic and isoinertial dynamometry and numerous field tests are used to assess muscular endurance. By understanding and monitoring endurance in athletes, the training workload during the preparation period and the the pre-competition and competition seasons can be implemented and corrected. The achievement and maintenance of optimal fitness should be regarded as a dynamic concept that requires continual monitoring that is aided by the modern methods of functional diagnoses.

Keywords: endurance, cardiorespiratory, muscle, athletes, training.

\section{SAŽETAK}

Kardiorespiratorna izdržljivost ili aerobna izdržljivost je sposobnost čitavog tela da održava dugotrajnu fizičku aktivnost $i$ uključuje relativno velike mišićne grupe. Mišićna izdržljivost predstavlja sposobnost mišića odnosno mišićne grupe da izvrši ponavljanje kontrakcije kroz period vremena dovoljan da izazove mišićni zamor ili sposobnost da održi specifični procenat maksimalne voljne kontrakcije u toku dužeg vremenskog perioda. Svaka ima jedinstven udeo u sportskim aktivnostima i svaka se razlikuje po svojoj važnosti, kod različitih sportista. Kardiorespiratorna izdržljivost se smatra najvažnijom komponentom fizičke pripremljenosti. Nizak kapacitet izdržljivosti vodi ka zamoru, čak i u sportovima i aktivnostima niže dinamike. Kao zlatni standard za ispitivanje kardiorespiratorne izdržljivosti smatra se kombinacija spiroergometrijskog testiranja (uz primenu ade$k v a t n o g$ protokola testiranja) $i$ određivanja nivoa laktatnih pragova. Dobijeni parametri se zatim koriste za definisanje ciljeva treninga i izradu preciznog plana i programa treninga, kao i za naknadnu evaluaciju efekata treninga Mišićna izdržljivost je specifična za svaku mišićnu grupu, tip i brzinu kontrakcije. Zbog toga ne postoji univerzalna procena mišićne izdržljivosti celog tela. Za procenu mišićne izdržljivosti koriste se metode izokinetičke i izoinercijalne dinamometrije, kao i brojni terenski testovi. Razumevanje i praćenje izdržljivosti kod sportista omogućava izradu $i$ korekciju individualnih zona trenažnog opterećenja u odgovarajućim ciklusima pripremnog perioda tokom predtakmičarske i takmičarske sezone. Postizanje i održavanje optimalnog stanja treniranosti treba shvatiti kao dinamički koncept koji zahteva stalno praćenje, primenom savremenih metoda funkcionalne dijagnostike sportista.

Ključne reči: izdržljivost, kardiorespiratorna, mišići, sportisti, trening.

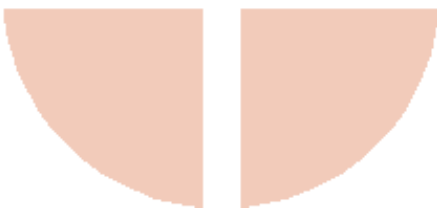




\section{BACKGROUND}

Endurance is a term in exercise physiology that describes two separate but closely related phenomena: cardiorespiratory endurance and muscular endurance. Each type of endurance plays a unique role in sport activities, and each has a special importance to different athletes. Endurance is a basic necessity for competition in certain sports (e.g., distance running, cycling, endurance swimming, cross-country skiing, etc.), but it is also an essential component of a large number of otherteam sports (e.g., football, rowing, tennis, basketball, etc.).

Cardiorespiratory endurance, or aerobic endurance, is the ability of the whole body to sustain prolonged exercise involving relatively large muscle groups (1). Cardiorespiratory endurance is related to the development of the ability of the cardiovascular and respiratory systems to maintain an oxygen supply to the muscles engaged in prolonged physical activity as well as to the muscle's ability to obtain the necessary energy by way of aerobic processes. This is the reason why the terms cardiorespiratory and aerobic endurance are commonly used as synonyms. With endurance training, more oxygen per unit of time can be supplied and used in activated muscles. These training improvements allow an athlete to be engaged with a greater intensity in a physical activity requiring endurance, without a deterioration in the quality of performance.

Muscle endurance is defined by the American College of Sports Medicine (ACSM) as the ability of a muscle group to execute repeated contractions over a period of time that is sufficient to cause muscular fatigue or the ability to maintain a specific percentage of the maximum voluntary contraction for a prolonged period of time (2). Therefore, muscle endurance is specific to certain muscles or muscle groups. In the routine practice of sport training, the most common criterion for muscle endurance is the number of resistance exercise repetitions that are performed until the moment of muscle failure.

A tThe individual endurance of an athlete is the baseline for the improvement of his/her ability, and improvements can result through training, including the maintenance of competitive abilities by competing in competitions (3), the avoidance of detraining due to a low training workload, and the avoidance of an overtraining syndrome and/or possible injuries due to a high of a training workload (4).

\section{ADAPTATIONS \\ TO ENDURANCE TRAINING}

Endurance improvement through regular aerobic training is the result of numerous adaptations to a training stimulus. Some adaptive processes occur within the muscles themselves, providing a more efficient transport and use of oxygen and energetic substrates. Other important changes occur in the cardiovascular system, improving the blood supply to and within muscles. Adaptive changes in a body during endurance training, including increased left ventricle dimensions, reduced peripheral blood vessel resistance, and increased blood volume, enable increased values of stroke volume during submaximal and maximal physical activity and at rest. Muscle blood flow is increased with endurance training due to an enlargement of the capillary network (by the formation of new and opening of the existing capillaries), a more efficient blood flow distribution, and an increase in blood volume. Increased blood volume is caused by an increase in blood plasma volume, which leads to a reduction in blood viscosity, facilitating circulation and oxygen supply (5). Endurance training results in lower blood pressure values during submaximal physical exercise. During maximal intensity physical exercise, the ,systolic pressure is elevated and the diastolic pressure is reducedas compared to the pre-training values (6).

Endurance training induces an increase in the number and size of mitochondria in the muscle fibres. The activity of many oxidative enzymes is increased as a consequence of adaptation to training. These muscular changes, combined the oxygen transport system adaptation, increases the capacity of oxidative metabolism and cardiorespiratory endurance (7). An adapted skeletal muscle contains more glycogenas compared to an unadapted muscle. Moreover, adapted muscles contain more fat in the form of triglycerides. The activity of many enzymes involved in the beta ( $\beta$ ) oxidation of fats increases with training, resulting in increased levels of free fatty acids (8). These changes result in the increased use of fats as an energy source, the saving of glycogen, and, thus, the createdevelopment of favourable conditions favorable for prolonged physical activity without exhaustion.

\section{CARDIORESPIRATORY ENDURANCE}

According to many published papers and textbooks on the science of sport, cardiorespiratory endurance is thought to be the most important component of physical fitness. Endurance is the athletes' best defence against exhaustion. Low endurance capacity leads to exhaustion, even in sports and activities characterised by low dynamics. For each athlete, regardless of their discipline or activity, fatigue is the main obstacle to optimal performance. Even slight fatigue may disturb the ability of an athlete to perform because of reduced muscle strength, prolonged reaction and movement times, reduced agility and neuromuscular coordination, reduced velocity of the entire body, and reduced concentration and nimbleness. The cardiorespiratory endurance of an athlete is determined by a large number of factors $(9,10)$, with the most important being age, gender, body mass, genotype, physical activity (degree of fitness), and acute and past diseases, among others.

Regardless of the degree of preparedness of a cardiovascular system to supply the working muscles with an adequate amount of blood, endurance is hampered if the 
respiratory system is unable to transport enough oxygen to satisfy the oxygen demand. The function of the respiratory system usually does not limit the ability to perform physical activities because ventilation can be increased to a higher degree than can cardiovascular function (11). The respiratory system undergoes specific adaptations during endurance training to enhance its efficiency. Pulmonary ventilation is usually not considered to be a limiting factor when performing physical, endurance exercises (12). However, some evidence suggests that in a highly trained athlete (13), at a certain point, the capacity of the pulmonary system for oxygen transport may be insufficient to satisfy the oxygen demand and insufficient to keep pace with the capacity of an adapted cardiovascular system.

The generally accepted parameters to assess cardiovascular endurance are the maximal oxygen uptake $\left(\mathrm{VO}_{2 \max }\right)$, lactate (aerobic) threshold, maximal lactate steady state (anaerobic threshold), and exercise economy.

Maximal oxygen uptake $\left(\mathrm{VO}_{2 \max }\right)$ is the maximum capacity of an individual's body to transport and use oxygen during exercise or physical activity. $\mathrm{VO}_{2 \max }$ is widely accepted as the single best measure of cardiovascular endurance.

The lactate (aerobic) threshold is defined as the increase of physical exercise at which point anaerobic glycolysis is markedly activated in the engaged muscles, and the lactic acid concentration is elevated as compared compared to the resting values (14). This threshold most commonly occurs at an intensity of $40-60 \% \mathrm{VO}_{2 \max }$ and when thea lactic acid blood concentration of approximately 1,5 -2 mmol/l.

The maximal lactate steady state (MLSS) or anaerobic threshold is defined as the intensity of physical exercise at which stable states of $\mathrm{VO}_{2}$ and lactic acid in the blood can still be achieved and reflects a balance between the accumulation and degradation of lactic acid (15). MLSS is most commonly reached at an intensity of approximately 80$90 \% \mathrm{VO}_{2 \max }$ (in untrained healthy subjects; $65-70 \% \mathrm{VO}_{2 \max }$ is reached in elite athletes up to $95 \% \mathrm{VO}_{2 \max }$ ) and when the lactate blood concentration is approximately 3-5 $\mathrm{mmol} / \mathrm{L}$.

Exercise economy is used to express the oxygen consumption required to perform a given exercise workload, whether the exercise is running, cycling, or any other endurance activity (16). Differences in the $\mathrm{VO}_{2}$ between individuals at similar exercise workloads illustrate the individual variation found in exercise economy.

With the above parameters, the intensity at the lactate threshold and MLSS can be expressed in terms of running speed (on a treadmill in $\mathrm{km} / \mathrm{h}$ ) or power (on a bicycle ergometer in watts, $\mathrm{kpm} / \mathrm{min}$ or $\mathrm{km} / \mathrm{h}$; in watts on sportspecific ergometers, such as swimming, rowing, kayak and other similar activities). In practice, the generated results are expressed as the percentages of the achieved maximal oxygen uptake $\left(\% \mathrm{VO}_{2 \max }\right)$, of the maximal speed achieved in the test (\%Vmax), of the maximal achieved intensity in the test (\%Pmax), and so on.

The tests used to measure cardiorespiratory endurance are classified in different ways related to: the test character (specific and non-specific), the performance mode (con- tinued and discontinued), the type of workload (fixed and progressive workload), and the performance place (laboratory and field tests). The question of the appropriate test choice has been addressed in numerous studies and is especially important in light of the advances in technology and the increased availability of particular field methods (heart rate monitors, GPS devices, calculators of energy expenditure, etc.). Traditionally, dosed test workload ergometers (arm crank or cycle ergometers) and treadmills have been most commonly used in laboratories. More specific ergometers for certain sports (swimming, rowing, kayaking, ski-running, skating, etc.) have been increasingly used as well.

The use of arm cranks or cycle ergometers in laboratory testing with precise workload dosing allows for the use of additional invasive and non-invasive diagnostic methods (17). Due to the sedentary position of the exerciser and the defined cyclic repetition of pedalingpedalling, the risk of injury is low during the testing exercises. The shortcoming of this test type is its lack of the sufficient involvement of large muscle groups such that local muscle endurance and, not general cardiorespiratory endurance, commonly limits the maximal achievable test results (18).

As a treadmill enables natural movements (walking or running) with the engagement of large muscle groups and without the requirement of specific skills of the examinee, it can be used for different examinee profiles. Comparative studies have shown that the measured values of $\mathrm{VO}_{2}$ during treadmill testing were 5-15\% higher as compared compared to cycle ergometer values (19). However, the differences in measured $\mathrm{VO}_{2 \max }$ in laboratory treadmill tests may be caused by the test protocols, limiting interlaboratory comparisons. Test protocols most commonly differ in the duration of particular workload stages, dynamics of workload increases during the tests, changes in treadmill inclination during the test, and so on. Continued progressive exercise tests are more commonly used and are performed until the maximum exhaustion of an athlete is reached by increasing the workload through increasing the treadmill speed, inclination, or a combination of the two. Test protocols with markedly rapid increases in workload and shorter total durations commonly do not register maximal $\mathrm{VO}_{2}$ values due to muscle failure. On the other hand, long test protocols may also result in slightly lower registered $\mathrm{VO}_{2 \max }$ values due to increased body temperature, significant dehydration, muscle pain, and loss of motivation of the examinee $(20,21)$. In certain cases, it is necessary to choose a specific test protocol that is most appropriate to the characteristics of the sport in question (3). The use of sport-specific ergometers in laboratory testing enables more precise endurance measurements due to a more true to life reproduction of a dynamic stereotype that is characteristic of the sport and enables better mechanical efficacy (with lower energy consumption) during the test execution.

The above has led to national Olympic committees appointing only one laboratory to perform a functional diag- 
nosis and to serve as a national reference institution to test all athletes in the preparation for the Summer or Winter Olympic Games. However, unresolved issues in laboratory testing and the measurement of $\mathrm{VO}_{2 \max }$ for sport competition purposes remain, including increased air resistance in open sport arenas and increased energy consumption with increasing treadmill inclination and changes in biomechanical parameters during the execution of a particular test protocol (the length and frequency of steps, the angular velocity and amplitude in major joints, the activation of particular muscle groups, etc.) $(22,23)$. An optimal laboratory test should provide most of the parameters required for a proper assessment of the level of physical fitness, definition of individual training areas, and control of the training workload. The combination of spiroergometric testing (with appropriate testing protocols) and the measurements of the lactate thresholds is believed to be the gold standard in the assessment of cardiorespiratory endurance. The generated parameters are then used to define the training objectives, to prepare a precise training plan and program, and to evaluate the effects of the subsequent training effect evaluation for $(3,24)$. The most obvious shortcoming of such an approach is its high economic price, limiting its use to only the top athletes and preventing its use by young talented athletes for whom training program corrections would represent the method to achieve top results.

\section{MUSCULAR ENDURANCE}

The ability of a muscle group to execute repeated contractions or to maintain a specific percentage of its maximum voluntary contraction depends on a number of factors: the contractile and metabolic characteristics of the muscle fibres, the position of the fibres during action, the activation of motor units, present fitness, etc. (25). Neuromuscular adaptation during sport training enables greater endurance to be demonstrated (26) and involves neurologic adaptation (more efficient motor unit activation), an enlargement of the transverse section of muscles, and changes in cellular metabolites. The magnitude of these changes depends on the initial status, type of muscular contraction, intensity and extent of training workload, number of series, selection and sequence of exercises, duration of rest, frequency of training, and movement velocity, among others. (27).

Muscular endurance is specific for each group of muscles, type , and velocity of contraction. As a result, there is no universal assessment for the muscular endurance of the whole body. The isokinetic and isoinertial dynamometry methods and numerous field tests are used to assess muscular endurance. During laboratory isokinetic tests, the angular velocity of a joint is controlled and kept constant; however the linear velocity of the active muscle group is not kept constant. Angular velocity increases at the beginning of each movement until the target velocity is reached. Further acceleration is not possible, and the movement is maintained at a constant velocity until the end of the planned movement. The advantages of isokinetic dynamometry in the assessment of muscular endurance include an optimal workload, an excellent confidence test, and a computer-aided assessment of muscular function. In addition, more advanced isokinetic systems have accessories to allow for the testing of different muscle groups, which is not possible in the associated joints. Except for the isolated movement tests, various manual activities (e.g., lifting and handling of various sport equipment) can be simulated on adapted isokinetic dynamometers with special accessories. The use of standardised protocols for isokinetic dynamometry is essential because of the related methodological issues, such as the positioning and motivation of the examinees during the test. Factors influenced by the positioning of the examinee and segment-joint stabilizisation during the test include the muscle group length, contribution of elastic components, effective torque, development of angular velocity, and inhibitory effects of antagonistic muscle groups $(28,29)$. Therefore, it is essential that these factors are standardised to assure the validity of inter-test comparisons. The major shortcomings of isokinetic dynamometry are a limited movement velocity, the absence of natural movements, and the high equipment costs. Isokinetic testing of an isolated joint does not require natural movements; therefore, and as such,the examinees have to be precisely instructed and examiners have to be well acquainted with the testing system and test requirements. An additional shortcoming of isokinetic dynamometers is their inability to achieve movement velocities specific for a particular sport activity.

In practice, the combination of isoinertial dynamometry and field tests is most commonly employed. Isoinertial dynamometry is a method that enables the simultaneous and precise measurement of a large number of parameters and is aided by various kinematic and ballistic measurement systems. The use of adequate equipment and standardised testing protocols enables the precise measurement of the effective force, distance covered, or movement duration. Depending on the device, a single or several parameters can be measured, and it is possible to calculate the data necessary for high quality diagnosis of muscular endurance using a computer (30). Isoinertial field tests are tests in which a constant external load is resisted during the entire exercise, such as free-weight exercises. In practical work, the term isoinertial reflects a test that determines the ability of an examinee to resist a maximal external load (31). A test with a single maximal repetition (1-repetition maximum-1RM) represents the maximum load resisted throughout the range of motion in a controlled way and with good posture (32). The biggest shortcoming of these field tests is the lack of appropriate validity and objectivity and the fact that such movements (e.g., bench press or squats, movements during push-ups, sit-ups, pull-ups, etc.) have little resemblance to most of the movements in sport activities. 


\section{CONCLUDING REMARKS}

By understanding and monitoring endurance in athletes, the training workload during the preparation period and the pre-competition and competition seasons can be implemented and corrected. The ua the the The achievement and maintenance of optimal fitness should be regarded as a dynamic concept that requires continual monitoring that is aided by the modern methods of functional diagnoses. The specific individual diagnosis of the endurance of an athlete is the basis for the preparation of a precise training plan and program and for the subsequent evaluation, correction, and improvement of the applied means and training methods. Using the generated parameters, training should be planned to result in better muscular endurance via specific neuromuscular adaptations. Moreover, properly guided endurance training should raise the lactate threshold and the level of maximal lactate balance via an increased oxygen supply to the active muscles and a reduced lactate production in the active muscles, resulting in delayed fatigue in the athlete.

\section{REFERENCES}

1.Wilmore JH, Costill DL, Kenney LW. Physiology of sport and exercise. 4th ed. Champaign, IL: Human Kinetics, 2008.

2.Humphries RB, Dugan E, Doyle T. Muscular Fitness. In American College of Sports Medicine, eds. ACSM's Resource Manual for Guidelines for Exercise Testing and Prescription. 5th ed. Philadelphia: Lippincott William \& Wilkins, 2006: 206-24.

3.Radovanovic D, Ponorac N, Ignjatovic A, Stojiljkovic N, Popovic T, Rakovic A. Specific alterations of physiological parameters in competitive race walkers. Acta Physiol Hung 2011; 98(4): 448-54.

4.Radovanovic D, Bratic M, Nurkic M, Cvetkovic T, Ignjatovic A, Aleksandrovic M. Oxidative stress biomarker response to concurrent strength and endurance training. Gen Physiol Biophys 2009; S28: 205-11.

5.McGuire DK, Levine BD, Williamson JW, et al. A 30year follow-up of the Dallas Bed Rest and Training study II. Effect of age on cardiovascular adaptation to exercise training. Circulation 2001; 104(12): 1358-66.

6.Levy WC, Cerqueira MD, Abrass IB, Schwartz RS, Stratton JR. Endurance exercise training augments diastolic filling at rest and during exercise in healthy young and older men. Circulation 1993; 88(1): 116-26.

7.Timmons JA. Variability in training-induced skeletal muscle adaptation. J Appl Physiol 2011; 110: 846-53.

8.Yeo WK, Carey AL, Burke L, Spriet LL, Hawley JA. Fat adaptation in well-trained athletes: effects on cell metabolism. Appl Physiol Nutr Metab 2011; 36(1): 12-22.

9.Bassett DR, Howley ET. Limiting factors for maximum oxygen uptake and determinants of endurance performance. Med Sci Sports Exerc 2000; 32: 70-84.
10. Coyle EF. Integration of the physiological factors determining endurance performance ability. Exerc Sport Sci Rev 1995; 23: 25-63.

11. Radovanovic D, Bratic M, Nurkic M, Stankovic N. Recovery of dynamic lung function in elite judoists after short-term high intensity exercise. Arch Budo 2011; 7(1): 21-26.

12. di Prampero PE (2003). Factors limiting maximal performance in humans. Eur J Appl Physiol 2003; 90: $420-9$.

13. Wagner PD. A theoretical analysis of factors determining ${ }^{~} \mathrm{VO}_{2 \max }$ at sea level and altitude. Respir Physiol 1996; 106: 329-43.

14. Barstow TJ, Casaburi R, Wasserman K. $\mathrm{O}_{2}$ uptake kinetics and the $\mathrm{O}_{2}$ deficit as related to exercise intensity and blood lactate. J Appl Physiol 1993; 75(2): 755-62.

15. Faude O, Kindermann T, Meye T. Lactate threshold concepts: how valid are they? Sport Med 2009; 39(6): 469-90.

16. Daniels JT. A physiologist's view of running economy. Med Sci Sports Exerc 1985; 17(3): 332-8.

17. Djordjevic D, Cubrilo D, Puzovic V, et al. (2012). Changes in athlete's redox state induced by habitual and unaccustomed exercise. Oxid Med Cell Longev 2012; doi:10.1155/2012/805850

18. Radovanovic D, Aleksandrovic M, Stojiljkovic N, Ignjatovic A, Popovic T, Marinkovic M. Influence of physical training on cardiorespiratory endurance in preadolescent age. Acta Med Mediane 2009; 48(1): 37-40.

19. Verstappen FT, Huppertz RM, Snoeckx LH (1982). Effect of training specificity on maximal treadmill and bicycle ergometer exercise. Int J Sports Med 3(1): 43-6.

20. Pollock ML, Bohannon RL, Cooper KH, et al. Comparative analysis of four protocols for maximal treadmill stress testing. Am Heart J 1976; 92(1): 39-46.

21. Kang J, Chaloupka EC, Mastrangelo MA, Biren GB, Robertson RJ. Physiological comparisons among three maximal treadmill exercise protocols in trained and untrained individuals. Eur J Appl Physiol 2001; 84(4): 291-5.

22. Pereira MA, Freedson PS. Intraindividual variation of running economy in highly trained and moderately trained males. Int J Sports Med 1997; 18(2): 118-24.

23. Riley PO, Dicharry J, Franz J, et al. A kinematics and kinetic comparison of overground and treadmill running. Med Sci Sports Exerc 2008; 40(6): 1093-110.

24. Radovanovic D, Okicic T, Ignjatovic A. Physiological profile of elite women water polo players. Acta Med Medianae 2007; 46(4): 48-51.

25. Komi PV. Strength and power in sport. 2nd ed. London: Blackwell Science, 2003.

26. Ignjatovic A, Radovanovic D, Stankovic R, Markovic Z, Kocic J. Influence of resistance training on cardiorespiratory endurance and muscle power and strength in young athletes. Acta Physiol Hung 2011; 98(3): 305-12. 
27. Radovanovic D, Ignjatović A. Physiological basis of force and strength training (In Serbian). Nis: Faculty of Sport and Physical Education University of Nis, 2009.

28. Osternig LR. Isokinetic dynamometry: implications for muscle testing and rehabilitation. Exerc Sport Sci Rev 1986; 14: 45-80.

29. Baltzopoulos V, Brodie DA. Isokinetic dynamometry. Applications and limitations. Sports Med 1989; 8(2):101-16.

30. Ignjatovic A, Markovic Z, Radovanovic D. Effects of 12-week medicine ball training on muscle strength and power in young female handball players. J Strength Cond Res 2012; 26(8): 2166-73.

31. Desqorces FD, Berthelot G, Dietrich G, Testa MS. Local muscular endurance and prediction of 1 repetition maximum for bench in 4 athletic populations. J Strength Cond Res 2010; 24(2): 394-400.

32. Shimano T, Kraemer WJ, Spiering BA, et al. Relationship between the number of repetitions and selected percentages of one repetition maximum in free weight exercises in trained and untrained men. J Strength Cond Res 2006; 20(4): 819-23. 